\title{
Assessment of Sarocladium oryzae Growth Inhibition, the Causal Agent of Rice Sheath Rot Disease, Using Methanol Extract of Binahong Leaves
}

\author{
Endah Yulia ${ }^{1}$, Silvia Rahma Dhiya Syafira², Fitri Widiantini ${ }^{1}$, Wawan Kurniawan ${ }^{1}$ \\ ${ }^{1}$ Department of Plant Pests and Diseases, Agriculture Faculty, Universitas Padjadjaran, Jatinangor, West Java, Indonesia, \\ 45363 \\ ${ }^{2}$ Alumnus of Agrotechnology study program, Agriculture Faculty, Universitas Padjadjaran, Jatinangor, West Java, Indonesia, \\ 45363 \\ *Corresponding Author: endah.yulia@unpad.ac.id
}

\begin{abstract}
Sheath rot disease caused by Sarocladium oryzae is an important disease on rice. The pathogen that infects uppermost leaf sheath enclosing to the young panicles can cause yield losses up to $85 \%$. Though the disease is commonly controlled using synthetic fungicides, the use of natural products that safer to the environment have been enormously explored. The research aimed to test growth inhibition of $S$. oryzae colony using methanol leaf extract of binahong (Anredera cordifolia). The research was carried out from June until December 2017 at the Laboratory of Biotechnology Plant Protection, Department of Plant Pest and Diseases, Faculty of Agriculture, Universitas Padjadjaran. The method used was Randomized Complete Design consisted of six treatments and four replications. The treatments were five concentrations of binahong leaf extract of $0.125 \%, 0.25 \%, 0.5 \%, 1 \%, 2 \%$ and one control treatment. The result showed that binahong leaf extract did not inhibit the growth of S. oryzae. The highest inhibition percentage of $4.55 \%$ at $0.25 \%$ concentration was considered to be a low inhibition category. Although the colony growth of $S$. oryzae was not significantly inhibited, the extract caused hyphal abnormalities. This actually shows the antifungal potency of the binahong leaf extract that needed further examination with more adequate methods.
\end{abstract}

Keywords : Anredera cordifolia, botanical pesticide, rice sheath rot

\section{ABSTRAK \\ Uji Penghambatan Pertumbuhan Jamur Sarocladium oryzae, Penyebab Penyakit Busuk Pelepah Padi, dengan Ekstrak Metanol Daun Binahong}

Penyakit busuk pelepah yang disebabkan oleh jamur Sarocladium oryzae merupakan penyakit penting pada tanaman padi. Patogen yang menginfeksi daun bendera dan malai ini dapat mengakibatkan kehilangan hasil mencapai $85 \%$. Pengendalian penyakit busuk pelepah umumnya dilakukan dengan menggunakan fungisida sintetik tetapi eksplorasi bahan alami yang lebih aman terhadap lingkungan telah banyak dilakukan. Penelitian ini bertujuan untuk menguji penghambatan pertumbuhan jamur S. oryzae dengan perlakuan ekstrak metanol daun binahong (Anredera cordifolia). Penelitian dilaksanakan pada bulan Juni sampai bulan Desember 2017 di Laboratorium Bioteknologi Proteksi Tanaman, Departemen Hama dan Penyakit Tumbuhan, Fakultas Pertanian, Universitas Padjadjaran. Metode penelitian yang digunakan adalah metode percobaan dengan Rancangan Acak Lengkap yang terdiri atas enam perlakuan dan empat ulangan. Perlakuan merupakan lima konsentrasi ekstrak metanol daun binahong yaitu $0,125 \%, 0,25 \%, 0,5 \%, 1 \%$, dan $2 \%$ serta satu perlakuan kontrol. Hasil penelitian menunjukkan ekstrak metanol daun binahong tidak dapat menghambat pertumbuhan koloni jamur $S$. oryzae. Persentase penghambatan tertinggi sebesar $4,55 \%$ pada konsentrasi uji $0,25 \%$ tergolong ke dalam kemampuan menghambat yang sangat rendah. Meskipun diameter koloni jamur tidak dihambat secara signifikan, perlakuan ekstrak metanol daun binahong dapat mengakibatkan abnormalitas hifa jamur $S$. oryzae. Hal tersebut menunjukkan adanya potensi antifungi ekstrak tanaman binahong untuk diteliti lebih lanjut dengan teknik dan metode yang lebih memadai.

Kata Kunci : Anredera cordifolia, pestisida alami, busuk pelepah padi

\section{PENDAHULUAN}

Penyakit busuk pelepah yang disebabkan oleh jamur Sarocladium oryzae pada tanaman padi masih menjadi kendala utama upaya peningkatan produksi padi. Penyakit ini dilaporkan dapat mengakibatkan kehilangan hasil mencapai $85 \%$ atau pada beberapa kasus dapat mengakibatkan gagal panen (Ayyadurai et al., 2005; Sakthivel, 2001; Surin \& Disthapom, 1977). Gejala awal adalah berupa lesi berwarna coklat keabuabuan pada daun bendera (Ou, 1985). Infeksi jamur pada daun bendera bagian atas yang terdapat malai muda dapat mengakibatkan pembentukan malai menjadi terhambat sehingga hanya menghasilkan sedikit biji atau bahkan menyebabkan malai tidak keluar (Chien \& Huang, 1979; Gopalakrishnan et al., 2010). Biji yang terinfeksi akan berubah warna dan menjadi steril sehingga hasil gabah dan kualitas biji menjadi menurun, demikian juga dengan viabilitas benih dan nilai gizi beras akan berkurang (Ayyadurai et al., 2005; Mew \& Gonzales, 2002).

Pengendalian penyakit akibat infeksi jamur pada tanaman padi umumnya dilakukan dengan menggunakan fungisida sintetik. Meskipun memberikan keefektifan yang tinggi, penggunaan pestisida sintetik dipercaya telah menimbulkan dampak negatif bagi lingkungan dan manusia tertutama karena pemakaian yang melebihi anjuran. Di lain pihak, kesadaran untuk melakukan manajemen penyakit yang lebih aman seperti eksplorasi dan 
penggunaan pestisida berbahan alami sudah semakinbesar. Beberapa senyawa alami tanaman menunjukkan bersifat toksik terhadap jamur patogen tumbuhan (Enyiukwu et al., 2014; Isman, 2000). Kelebihan dari penggunaan pestisida nabati antara lain yaitu harga relatif murah dan aman, cepat terdegradasi, tidak menyebabkan keracunan pada tanaman, serta mudah dibuat dan diaplikasikan (Sudarmo \& Mulyaningsih, 2014).

Beberapa penelitian juga telah dilakukan untuk pengendalian penyakit busuk pelepah pada padi. Narasimhan et al. (1998) menyatakan bahwa formulasi EC ekstrak minyak Azadirachta indica dan Pometia pinnata mampu mencegah penyakit busuk pelepah. Ekstrak etanol Citrus medica dilaporkan dapat menghambat pertumbuhan radial $S$. oryzae secara in vitro dengan penghambatan sebesar $90 \%$ (Shamsi \& Chowdhury, 2016). Kumar \& Patibanda (2015) melaporkan bahwa tanaman Allium sativum, Allium cepa, Aloe vera, Eucalyptus odorata, Curcuma longa dan Ocimum basilicum dapat menghambat pertumbuhan $S$. oryzae dengan penghambatan tertinggi oleh $A$. sativum konsentrasi $20 \%$ dan $25 \%$ yaitu sebesar $100 \%$. Selain itu, ekstrak dari tanaman Acorus calamus mampu menghambat pertumbuhan $S$. oryzae hingga 92\% (Meera \& Balabaskar, 2012).

Tanaman binahong (Anredera cordifolia (Ten.) Steenis) merupakan tanaman dari famili Basellaceae yang sudah sering dimanfaatkan sebagai obat tradisional di bidang kesehatan manusia (Djamil et al., 2012; Manoi, 2009; Palmer \& Senaratne, 2012). Tanaman binahong dilaporkan mengandung senyawa alkaloid, polifenol, flavonoid, saponin, dan antrakuinon yang dapat bersifat sebagai senyawa antimikroba (Astuti et al., 2011; Aulifa dkk., 2014; Katno, 2006). Tanaman ini memiliki kandungan senyawa metabolit sekunder seperti flavonoid pada bagian daun, batang, umbi dan bunga (Harborne, 1973).

Hasil penelitian sebelumnya menunjukkan ekstrak air daun binahong mampu menekan pertumbuhan jamur Colletotrichum spp. dan Fusarium spp. dengan persentase penekanan masingmasing sebesar $66,95 \%$ dan $38,67 \%$ meskipun pada beberapa pengujian menunjukkan hasil yang kurang stabil (Widiantini dkk., 2016; Yulia dkk., 2016). Untuk meningkatkan keefektifan ekstrak, ekstraksi tanaman dapat dilakukan dengan menggunakan pelarut organik seperti metanol. Di dalam proses ekstraksi tanaman, jenis pelarut yang digunakan akan berpengaruh terhadap kualitas ekstrak tanaman berkaitan dengan kandungan senyawa dalam ekstrak maunpun keefektifannya (Gurjar et al., 2012). Penelitian ini bertujuan untuk menguji keefektifan ekstrak metanol daun binahong untuk menghambat pertumbuhan jamur $S$. oryzae, penyebab penyakit busuk pelepah pada tanaman padi.

\section{BAHAN DAN METODE}

Penelitian dilakukan di Laboratorium Bioteknologi Proteksi Tanaman, Departemen Hama dan Penyakit Tumbuhan, Fakultas Pertanian, Universitas Padjadjaran dari bulan Juni sampai Desember 2017. Metode penelitian yang digunakan adalah metode eksperimen dengan Rancangan Acak Lengkap (RAL) dengan 6 perlakuan yaitu 5 konsentrasi ekstrak metanol daun binahong $0,125 \%$, $0,25 \%, 0,5 \%, 1 \%$, dan $2 \%$ serta 1 perlakuan kontrol yang diulang 4 kali. Data dari hasil pengujian dianalisis secara statistik dengan menggunakan program SPSS Versi 17. Pengujian perbedaan antar perlakuan dilakukan menggunakan Analisis Varians dengan taraf nyata $5 \%$. Jika terjadi perbedaan nilai F hitung yang nyata, maka dilakukan uji lanjutan dengan Uji Lanjut Duncan pada taraf nyata 5\%.

\section{Isolasi Jamur Sarocladium oryzae}

Isolasi patogen dilakukan seperti yang diuraikan di dalam Agrios (2005). Potongan bagian pelepah padi bergejala disterilisasi dengan menggunakan alkohol $70 \%$ dan natrium hypoklorit 1\%. Kemudian dibilas dengann akuades steril dan selanjutnya ditempatkan pada kertas saring steril untuk menghilangkan ekses larutan. Potongan daun diletakkan pada media tumbuh Potato dextrose agar (PDA) dan diinkubasikan pada suhu ruang $\left( \pm 28^{\circ} \mathrm{C}\right)$. Miselium yang tumbuh kemudian dipindahkan ke media PDA yang baru sebagai biakan murni jamur $S$. oryzae.

\section{Penyiapan Ekstrak Metanol Daun Binahong}

Daun tanaman binahong diperoleh dari daerah Jatinangor, Kabupaten Sumedang, Jawa Barat. Daun yang digunakan merupakan campuran daun yang tua dan daun yang masih muda, daun dicuci dan dikeringudarakan di dalam suhu ruang selama satu hari. Daun binahong kemudian dioven pada suhu $45^{\circ} \mathrm{C}$ selama \pm 12 jam untuk mengurangi kadar air daun. Daun kering oven tersebut kemudian dijadikan serbuk. Ekstrak metanol daun binahong disiapkan melalui cara ekstraksi dengan metode maserasi (Dono dkk., 2008; Aulifa dkk., 2014). Serbuk daun binahong direndam di dalam pelarut metanol menggunakan perbandingan bahan dan pelarut metanol 1:10 (w/v) selama 2 hari di dalam wadah tertutup. Selanjutnya dilakukan penyaringan menggunakan kertas saring dan dilakukan penguapan dengan rotary evaporator pada suhu $55-60^{\circ} \mathrm{C}$ dan panghampaan pada tekanan 580-600 mmHg. Hasil ekstraksi berupa lengketan disimpan di dalam botol pada suhu $\pm 4^{\circ} \mathrm{C}$ sampai digunakan.

\section{Uji Penghambatan Pertumbuhan Koloni Jamur $S$. oryzae}

Pengujian penghambatan pertumbuhan koloni jamur $S$. oryzae dilakukan dengan menggunakan 
teknik poisoned food (Hubert et al., 2015). Ekstrak daun binahong ditimbang masing-masing sebanyak 2,4 g, 1,2 g, 0,6 g, 0,3 g, dan 0,15 g dan dimasukkan langsung ke dalam $120 \mathrm{ml}$ PDA $\left( \pm 50^{\circ} \mathrm{C}\right)$ untuk membuat konsentrasi uji $2 \%, 1 \%, 0,5 \%, 0,25 \%$ dan $0,125 \%$. Campuran tersebut $(15 \mathrm{ml})$ kemudian dituangkan ke dalam cawan Petri dan dibiarkan memadat. Perlakuan kontrol merupakan media PDA tanpa penambahan ekstrak. Potongan agar-miselium jamur $S$. oryzae $(\varnothing 5 \mathrm{~mm})$ diletakkan pada bagian tengah cawan Petri dan siapan ini dinkubasikan pada suhu ruang.

Pengamatan dilakukan dengan mengukur diameter koloni jamur mulai satu hari setelah inkubasi sampai koloni jamur pada perlakuan kontrol memenuhi permukaan media dengan interval pengamatan 7 hari. Persentase penghambatan dihitung dengan rumus sebagai berikut:

$\mathrm{I}=\frac{(\mathrm{C}-\mathrm{T}) \times 1}{\mathrm{C}} 100 \%$

Keterangan:

$\mathrm{I}=$ Persen penghambatan $(\%)$

$\mathrm{C}=$ Diameter koloni pada perlakuan kontrol $(\mathrm{cm})$

$\mathrm{T}=$ Diameter koloni pada perlakuan ekstrak $(\mathrm{cm})$
Pengamatan secara mikroskopis juga dilakukan untuk melihat pengaruh ekstrak terhadap kerusakan miselium atau hifa jamur $S$. oryzae karena perlakuan ekstrak daun binahong. Keadaan miselium atau hifa jamur $S$. oryzae pada perlakuan ekstrak dibandingkan dengan pada perlakuan kontrol untuk mengamati kemungkinan terjadinya abnormalitas hifa (malformasi) karena perlakuan ekstrak. Abnormalitas hifa jamur ditandai dengan adanya pembengkokan, miselium pecah, miselium kerdil, lisis, adanya hifa yang putus, membengkak dan keriting (Lorito et al., 1993).

\section{HASIL DAN PEMBAHASAN}

Hasil pengujian menunjukkan bahwa ekstrak metanol daun binahong tidak secara signifikan dapat menghambat pertumbuhan koloni jamur $S$. oryzae (Tabel 1). Pertumbuhan koloni jamur $S$. oryzae pada perlakuan ekstrak metanol daun binahong konsentrasi rendah $0,125 \%$ dan $0,25 \%$ lebih lambat dibandingkan dengan pada perlakuan kontrol tetapi tidak berbeda nyata secara statistik. Hasil pengujian ekstrak pada konsentrasi yang lebih tinggi $(0,5 \%, 1 \%$ dan $2 \%)$ bahkan menunjukkan hasil pertumbuhan koloni jamur $S$. oryzae yang lebih cepat dibandingkan dengan kontrol.

Tabel 1. Diameter koloni jamur S. oryzae dan persentase penghambatan pertumbuhan S. oryzae pada perlakuan ekstrak metanol daun binahong

\begin{tabular}{lcc}
\hline \multicolumn{1}{c}{ Perlakuan } & $\begin{array}{c}\text { Diameter koloni jamur } S . \\
\text { oryzae }(\mathrm{cm}) \pm \mathrm{SE}\end{array}$ & $\begin{array}{c}\text { Penghambatan pertumbuhan } \\
\text { jamur } \\
\text { S. oryzae }(\%)\end{array}$ \\
\hline Kontrol & $6,46 \mathrm{a} \pm 0,169$ & - \\
Konsentrasi $0,125 \%$ & $6,32 \mathrm{a} \pm 0,248$ & 2,22 \\
Konsentrasi $0,25 \%$ & $6,17 \mathrm{a} \pm 0,376$ & 4,55 \\
Konsentrasi $0,5 \%$ & $6,75 \mathrm{a} \pm 0,284$ & $\mathrm{Tm}$ \\
Konsentrasi $1,0 \%$ & $6,80 \mathrm{a} \pm 0,303$ & $\mathrm{Tm}$ \\
Konsentrasi $2,0 \%$ & $7,01 \mathrm{a} \pm 0,655$ & $\mathrm{Tm}$ \\
\hline
\end{tabular}

Keterangan: Huruf yang sama pada satu kolom dalam tabel menunjukkan data tidak berbeda nyata berdasarkan Uji Jarak Berganda Duncan 5\%. SE = Standard Error. Tm = Tidak menghambat.

Dari hasil yang diperoleh dapat dikatakan bahwa ekstrak metanol daun binahong tidak dapat menghambat pertumbuhan jamur $S$. oryzae. Meskipun perlakuan ekstrak konsentrasi $0,25 \%$ menunjukkan penghambatan pertumbuhan jamur $S$. oryzae tetapi pesentase penghambatan tertinggi sebesar 4,55\% dapat digolongkan sangat rendah. Mori et al. (1997) menyebutkan bahwa penghambatan pertumbuhan jamur dikategorikan lemah apabila persentase penghambatan di bawah $25 \%$.

Penghambatan yang lemah ini diduga karena senyawa metabolit sekunder yang bersifat antimikroba di dalam ekstrak metanol daun binahong jumlahnya sedikit. Saifudin (2014) menyatakan bahwa bahan tanaman yang berasal dari bagian daun memiliki beragam senyawa metabolit sekunder, namun metabolit sekunder tersebut sulit untuk didapatkan karena matriks nabati dan kompleksnya jaringan.
Jenis pelarut dan metode ekstraksi juga dapat memengaruhi keefektifan ekstrak yang diuji. Gurjar et al. (2012) menyebutkan bahwa jumlah kandungan senyawa metabolit sekunder dalam tanaman dipengaruhi oleh bahan tanaman, jenis pelarut dan metode ekstraksi yang digunakan. Daun binahong yang digunakan pada penelitian ini tidak dipisahkan secara pasti antara daun muda dan daun tua sehingga hal ini juga dapat berpengaruh terhadap jumlah senyawa bioaktif yang terkandung dan terekstraksi. Hasbullah (2016) melaporkan bahwa daun tua tanaman binahong mengandung saponin lebih tinggi daripada pada daun muda.

Pada perlakuan ekstrak metanol daun binahong konsentrasi tinggi ada indikasi ukuran diameter koloni jamur lebih besar daripada pada perlakuan kontrol meskipun tidak berbeda nyata secara statistik. Kejadian penghambatan yang lebih rendah pada 
konsentrasi tinggi diduga karena terdapat senyawa pada ekstrak metanol daun binahong yang bersifat menstimulasi atau merangsang pertumbuhan miselium jamur S. oryzae. Bautista-Banos et al. (2003) dan Levin et al. (1988) menyebutkan bahwa terdapat suatu senyawa di dalam ekstrak tumbuhan yang dapat merangsang pertumbuhan jamur dan menutupi efek penghambatannya.

Hampir semua jamur dapat didukung pertumbuhannya oleh gula, terutama gula D-glukosa. Tanaman binahong memiliki kandungan senyawa mono polisakarida seperti L-arabinosa, D-galaktosa, dan L-rhamnosa sehingga ada kemungkinan bahwa stimulasi pertumbuhan jamur $S$. oryzae terjadi akibat adanya senyawa gula dalam ekstrak. Mohan \& Subramanian (1978) menyatakan bahwa senyawa golongan gula (sukrosa, amilum, glukosa dan maltosa) dapat mendukung pertumbuhan jamur $S$. oryzae.

Pertumbuhan jamur $S$. oryzae tergolong lambat. Pengamatan terakhir dilakukan pada 35 hari setelah perlakuan (Gambar 1). Saat pengamatan hari ke-5, sudah menunjukkan adanya penghambatan, demikian juga pada pengamatan yang dilakukan hingga hari ke-9 menunjukkan persentase penghambatan terhadap jamur $S$. oryzae terus meningkat. Namun pada pengamatan hari ke-12 hingga pengamatan hari ke-35, persentase penghambatan menjadi menurun. Karakteristik pertumbuhan yang lambat ini juga diduga berpengaruh terhadap keefektifan ekstrak di dalam menghambat pertumbuhan jamur.

Hasil pengamatan mikroskopis menunjukkan bahwa ekstrak daun binahong memengaruhi karakteristik miselium atau hifa jamur $S$. oryzae. Pada perlakuan ekstrak, terjadi abnormalitas hifa seperti hifa yang keriting, bengkok dan membelit (Gambar 2). Kondisi tersebut dibandingkan dengan keadaan hifa normal pada perlakuan kontrol yang tumbuh lurus, tidak beraturan dan bercabang. Hifa jamur $S$. oryzae umumnya memiliki lebar 1-1,5 $\mu \mathrm{m}$ dan beberapa hifa tidak beraturan dengan diameter hingga 2,5 $\mu \mathrm{m}$ serta bercabang (Pearce et al., 2001). Abnormalitas hifa dapat disebabkan oleh adanya senyawa metabolit sekunder yang bersifat antifungi pada ekstrak tanaman (Falah dkk., 2015; Yuniarti, 2010).
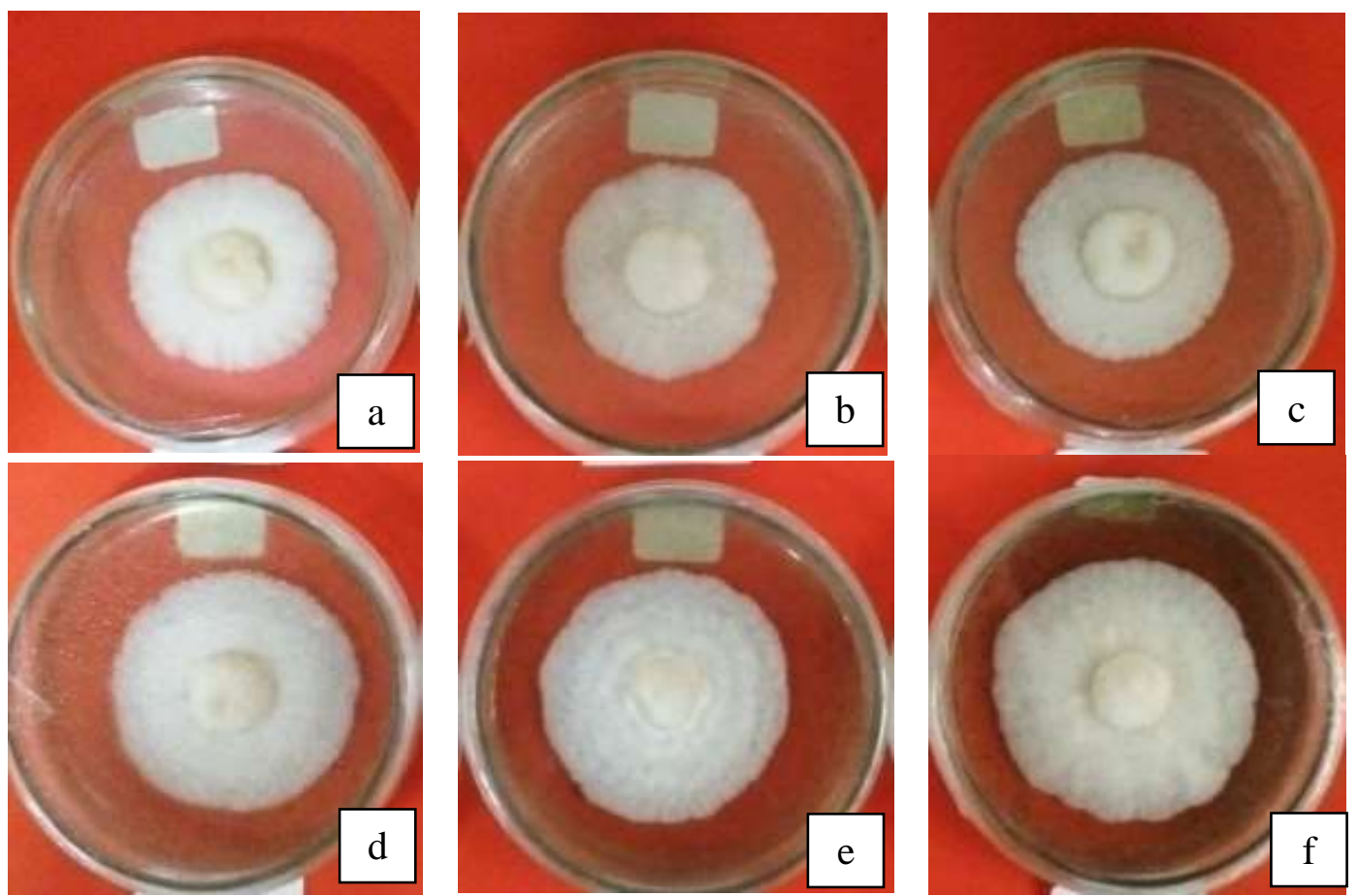

Gambar 1. Pertumbuhan jamur S. oryzae pada perlakuan ekstrak metanol daun binahong pada 35 HSP. (a) Kontrol. (b) Konsentrasi 0,125\%. (c) Konsentrasi 0,25\%. (d) Konsentrasi 0,5\%. (e) Konsentrasi $1 \%$. (f) Konsentrasi $2 \%$. 

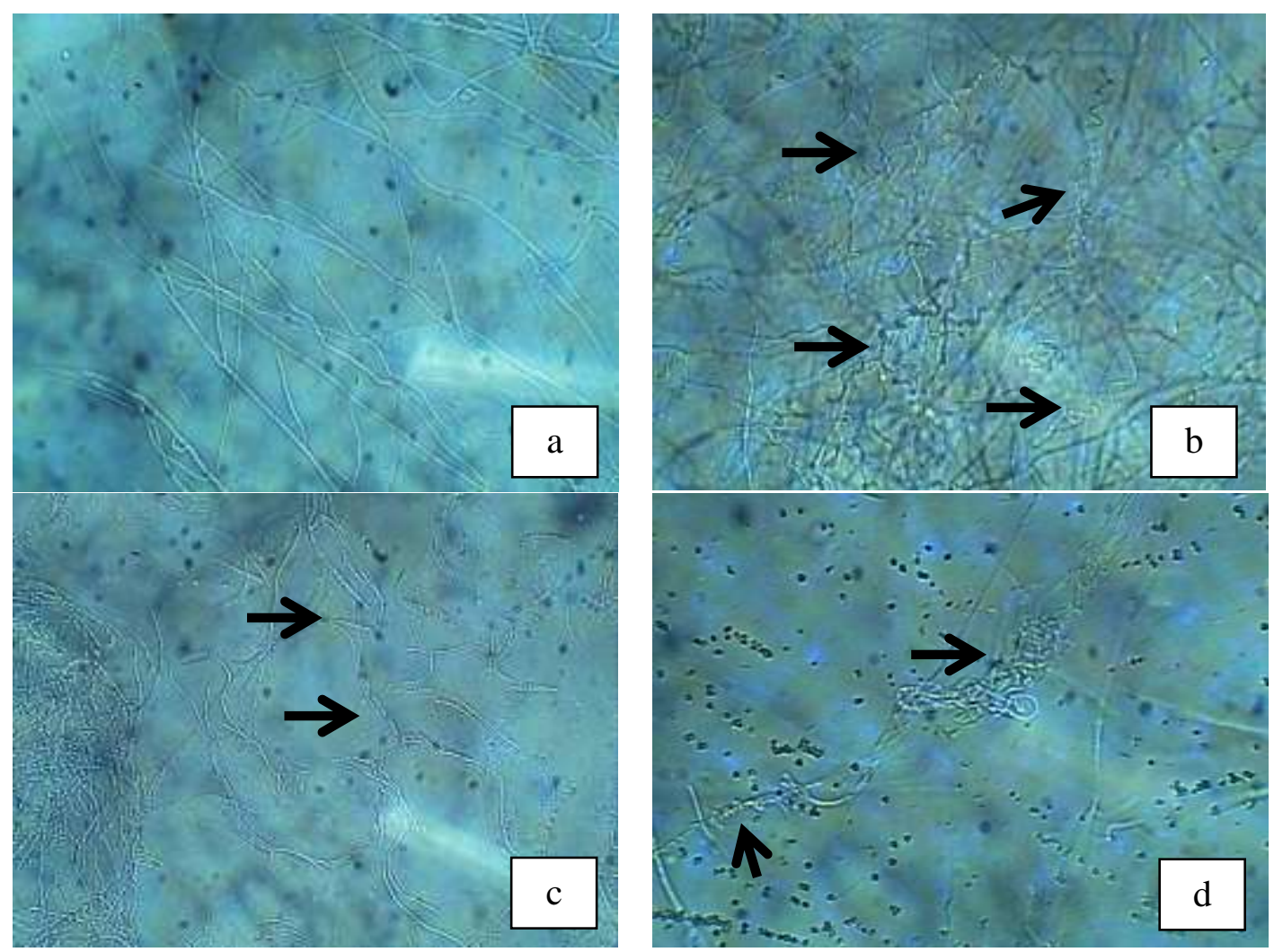

Gambar 2. Karakteristik hifa jamur S. oryzae pada perlakuan ekstrak metanol daun binahong. (a) Hifa normal pada perlakuan kontrol. (b) Hifa keriting. (c) Hifa membengkok. (d) Hifa membelit.

\section{UCAPAN TERIMAKASIH}

Terimakasih disampaikan kepada Universitas Padjadjaran atas dukungan dana penelitian Hibah Internal Unpad (HIU) tahun anggaran 2017.

\section{SIMPULAN}

Ekstrak metanol daun binahong tidak dapat menghambat pertumbuhan koloni jamur $S$. oryzae. Persentase penekanan pertumbuhan koloni jamur $S$. oryzae tergolong rendah dengan penekanan tertinggi sebesar $4,55 \%$ pada konsentrasi 0,25\%. Ekstrak metanol daun binahong mengakibatkan terjadinya abnormalitas hifa jamur $S$. oryzae meskipun tidak menghambat pertumbuhan diameter koloni jamur secara signifikan.

\section{DAFTAR PUSTAKA}

Agrios, G.N. 2005. Plant Pathology. $5^{\text {th }}$ ed. San Diego: Elsevier Academic Press.

Astuti, S.M., A.M. Mimi Sakinah, B.M. Retno Andayani, \& A. Risch. 2011. Determination of saponin compound from Anredera cordifolia (Ten) Steenis plant (binahong) to potensial treatment for several diseases. Journal of Agricultural Sciences. 3(4): 224-232.

Aulifa, D.L., I.N.P. Aryantha, \& Sukarno. 2014. Aktivitas anti jamur ekstrak metanol dari tumbuhan rempah-rempahan. Bionatura-Jurnal Ilmu-ilmu Hayati dan Fisik. 16 (1): 10-15.

Ayyadurai, N., S.I. Kirubakaran, S. Srisha, \& N. Sakthivel. 2005. Biological and molecular variability of Sarocladium oryzae, the sheath rot pathogen of rice (Oryza sativa L.). Current Microbiology. 50: 319-323.

Bautista-Banos, S., M. Hernandez-Lopez, E. BosquezMolinab, \& C.L. Wilson. 2003. Effects of chitosan and plant extracts on growth of Colletotrichum gloeosporioides, anthracnose levels and quality of papaya fruit. Crop Protection. 22: 1087-1092.

Chien, C.C., \& C.H. Huang. 1979. The relation between sheath rot and the sterility of rice plant. Journal Agriculture China. 28: 7-16.

Djamil, R., P.S. Wahyudi, S. Wahyono, \& M. Hanafi. 2012. Antioxidant activity of flavonoid from Anredera cordifolia (Ten) Steenis leaves. International Research Journal of Pharmacy. 3(9): 241-243.

Dono, D., S. Hidayat, C. Nasahi, \& E. Anggraini. 2008. Pengaruh ekstrak biji Barringtonia asiatica L. (Kurz) (Lecythidaceae) terhadap mortalitas larva dan fekunditas Crocidolomia pavonana F. (Lepidoptera: Pyralidae). Jurnal Agrikultura. 19(1): 5-14. 
Enyiukwu, D.N., A.N. Awurum, C.C. Ononuju, \& J.A. Nwaneri. 2014. Significance of characterization of secondary metabolites from extracts of higher plants in plant disease management. International Journal of Advance Agricultural Research. 2: 8-28.

Falah, S., Achmad, \& A. Winara. 2015. Aktivitas antifungi ekstrak akar mahoni terhadap isolat Botryodiplodia theobromae Pat. penyebab mati pucuk pada bibit jabon. Jurnal Ilmu Teknologi Kayu Tropis. 13(1): 1-10.

Gopalakrishnan, C., A. Kamalakannan, \& V. Valluvaparidasan. 2010. Effect of seedborne Sarocladium oryzae, the incitant of rice sheath rot on rice seed quality. Journal of Plant Protection Research. 50(1): 98-102.

Gurjar, M.S., S. Ali, M. Akhtar, \& K.S. Singh. 2012. Efficacy of plant extracts in plant disease management. Agricultural Sciences. 3(3): 425433.

Harborne, J.B. 1973. Phytochemical Methods: A Guide to Modern Techniques of Plant Analysis. London: Chapman and Hall.

Hasbullah, U. H. A. 2016. Kandungan senyawa saponin pada daun, batang dan umbi tanaman binahong (Anredera cordifolia (Ten) Steenis). Planta Tropika Journal of Agro Science. 4(1): 20-24.

Hubert, J., R.B. Mabagala, \& D.P. Mamiro. 2015. Efficacy of selected plant extracts against Pyricularia grisea, causal agent of rice blast disease. American Journal of Plant Sciences. 6: 602-611.

Isman, M. B. 2000. Plant essential oils for pest and disease management. Crop Protection. 19: 603608.

Katno, Dyah S., M. Rohmat, \& W. Harto. 2006. Inventaris Tanaman Obat Indonesia. Edisi VI. Jakarta: Departemen Kesehatan Badan Penelitian dan Pengembangan Kesehatan Balai Penelitian Tanaman Obat.

Kumar, Y.S. \& A.K. Patibanda. 2015. Bioefficacy of fungicides, botanicals, and biocontrol agents against Sarocladium oryzae, incitant of rice sheath rot. Journal of Agriculture and Veterinary Science. 8(12): 52-56.

Levin, H., R. Hazenfratz, J. Friedman, D. Palevitch, \& M. Perl. 1988. Partial purification and some properties of an antibacterial compound from Aloe vera. Phytotherapy Research. 2(2): 67-69.

Lorito, M., G.E. Harman, C.K. Hayes, R.M. Broadway, A. Tronsmo, S.L. Woo, \& A.D. Pietro. 1993. Chitinolytic enzymes produced by Trichoderma harzianum: antifungal activity of purified endochitinase and chitobiosidase. Molecular Plant Pathology. 83(3): 302-307.

Manoi, F. 2009. Binahong (Anredera cordifolia) sebagai obat. Warta Penelitian dan Pengembangan Tanaman Industri. 15(1): 3-5.
Meera, T., \& P. Balabaskar. 2012. Antifungal activity of botanicals against Sarocladium oryzae causing rice sheath rot disease. International Journal of Food, Agriculture and Veterinary Sciences. 2(1): 121-127.

Mew, T.W., \& P. Gonzales. 2002. A Handbook of Rice Seed-Borne Fungi. Philippines: International Rice Research Institute and USA: Science Publishers Inc.

Mohan, R., \& C.L. Subramanian. 1977. Influence of nitrogen nutrition and sheath rot disease on sugar contents of two paddy varieties. Current Science. 46(21): 753-755.

Mori, M., M. Aoyama, S. Doi, A. Kanetoshi, \& T. Hayashi. 1997. Antifungal activity of bark extract of deciduous trees. Holz als Roh und Werkstoff. 55: 130-132.

Narasimhan, V., K. Rajappan, C. Ushamalini, \& A.A. Kareem. 1998. Efficacy of new EC formulations of neem oil and pungam oil for the management of sheath root disease of rice. Phytoparasitica. 26: 301-306.

Ou, S.H. 1985. Rice Diseases, $2^{\text {nd }}$ ed. Surrey: Commonwealth Mycological Institute.

Palmer, B., \& W. Senaratne. 2012. Anredera cordifolia (Ten.) Steenis - Madeira vine. In M. Julien, R. McFadyen \& J. Cullen (Eds.). Biological Control of Weeds in Australia. Australia: CSIRO Publishing.

Pearce, D.A., P.D. Bridge, \& D.L. Hawksworth. 2001. Species concept in Sarocladium, the causal agent of sheath rot in rice and bamboo blight. Pp. 285-292. In S. Sreenivasaprasad \& R. Johnson (Eds.). Major Fungal Disease in Rice Recent Advances. Netherlands: Kluwer Academic Publishers.

Saifudin, A. 2014. Senyawa Alam Metabolit Sekunder: Teori, Konsep, dan Teknik Pemurnian. Yogyakarta: Deepublish.

Sakthivel, N. 2001. Sheath rot disease of rice: current status and control strategies. Pp. 271-283. In S. Sreenivasaprasad \& R. Johnson (Eds.). Major Fungal Disease in Rice Recent Advances. Netherlands: Kluwer Academic Publishers.

Shamsi, S., \& P. Chowdhury. 2016. In vitro evaluation of fungicides and some plant extract against rice sheath rot pathogen Sarocladium oryzae. Bangladesh Journal of Scientific Research. 29(1): 47-54.

Sudarmo, S., \& S. Mulyaningsih. 2014. Mudah Membuat Pestisida Nabati Ampuh. Jakarta: Agromedia Pustaka.

Surin, A.S., \& S. Disthaporn. 1977. Rice absortion of Sarocladium oryzae-a serious rice disease in Thailand. International Rice Research Newsletter. 2(5): 16-17. 
Widiantini, F., E. Yulia dan Riska. 2016. Uji keefektifan ekstrak air daun binahong (Anredera cordifolia (Ten.) Steenis) terhadap patogen penyebab penyakit layu fusarium (Fusarium oxysporum Schlecht. f.sp. lycopersici (Sacc.) Synd. et Hans.) pada tomat. Prosiding Seminar Nasional Perkumpulan Agroteknologi/Agroekologi Indonesia (PAGI). Surakarta 21 Juli 2016.

Yulia, E., F. Widiantini, A. Purnama, \& I. Nurhelawati. 2016. Keefektifan ekstrak air daun binahong (Anredera cordifolia (Ten.) Steenis) dalam menekan pertumbuhan koloni dan perkecambahan konidia jamur Colletotrichum capsici penyebab penyakit antraknos pada cabai. Jurnal Agrikultura. 27(1): 16-22.

Yuniarti. 2010. Kajian pemanfaatan ekstrak kulit Acacia mangium Willd. sebagai antifungi dan pengujiannya terhadap Fusarium sp. dan Ganoderma sp. Sains dan Terapan Kimia. 4(2): 190-198. 